\title{
Tradução e Apresentação da Diatribe de Epicteto 1.5
}

Aldo Dinucci

Rodrigo Pinto de Brito

1. Histórico da disputa entre céticos e estoicos acerca do conceito de representação (phantasía)

A diatribe 1.5 de Epicteto (intitulada Contra os Acadêmicos) faz referência ao ceticismo antigo, cujo desenvolvimento histórico é usualmente dividido de acordo com as seguintes fases ${ }^{1}$ :

1- Protoceticismo: ceticismo como atitude e procedimento parcialmente presente mesmo em filósofos dogmáticos, como, por exemplo, Heráclito, Xenófanes, Empédocles, Leucipo e Demócrito, e sofistas, como Protágoras e Górgias;

2- Primeiro Pirronismo: referente à vida de Pirro de Élis (360-270 a.C.) e seus sucessores, os convivas e comensais de Pirro, notadamente Nausífanes, mestre de Epicuro, e Timão de Fliunte (320-230 a.C.);

3- Ceticismo Acadêmico ou Média Academia: caracterizado pela adesão a asserções dogmáticas negativas e querelas, principalmente contra epicuristas e estoicos, empreendidas por Arcesilao (315-241 a.C), Carnéades (213-129 a.C) e Clitômaco (187109 a.C.);

4- Neopirronismo: caracterizado pelo reavivamento do pirronismo por Enesidemo de Cnossos (I a.C.) e começo da 'sistematização' do ceticismo pirrônico, inclusive com a organização dos tropos céticos, atribuídos a Enesidemo e Agripa;

5- Infiltração do Neopirronismo nas seitas médicas, com os obscuros Zeuxipos, Zeuxis, Antíoco de Laodiceia, todos de 1 a.C., e ainda Menodoto de Nicomédia $(f l$. $c$. 80), Teodás de Laodiceia (fl. c. 120), Heródoto de Tarso (fl. c. 150-180) e, finalmente, Sexto Empírico (fl. c. 200), expoente máximo do ceticismo pirrônico.

$\mathrm{Na}$ diatribe 1.5, as discussões empreendidas devem ser interpretadas como a réplica epicteteana aos ataques que os acadêmicos fizeram aos estoicos desde a

\footnotetext{
${ }^{1}$ Cf. Brochard, Victor. Os Céticos Gregos. São Paulo: Editora Odysseus, 2010.
} 
fundação da Stoá por Zenão de Cítio (334-262 a.C.). Assim, uma vez que Epicteto é herdeiro dessa discussão, urge fazer um sintético retrospecto das posições e argumentações acadêmicas contra os estoicos relativamente ao tópico em questão. Aqui tão somente apresentaremos os argumentos de ambas as partes, deixando para um trabalho posterior um estudo crítico deles.

Como se sabe, os critérios estoicos da verdade e da ação correta são a adesão à representação compreensiva (phantasía kataleptikế). Agir de acordo com ela fornece o caminho pelo qual gradualmente se pode escapar da ignorância em direção à sabedoria, evitando a falsidade da representação não compreensiva. Para tal, de acordo com as primeiras formulações estoicas do conceito de phantasía, há três critérios básicos que indicam quando uma representação é compreensiva, quais sejam: (i) ser derivada de um objeto existente; (ii) ser conforme ao objeto existente; (iii) ser impressa e estampada na alma ( $D L$ 7.46). De acordo com esses critérios, para os estoicos, a maioria esmagadora das representações é compreensiva e, assim, mesmo pessoas comuns agem em conformidade com elas. Contudo, tais pessoas agem de acordo com meras opiniões, pelo que suas ações não são louváveis, uma vez que não há um cálculo decisório como o do sábio estoico, que, possuidor de conhecimento irrefutável e executando ações com segurança inabalável (Cf. $D L$ 7.121-123), dá assentimento às representações compreensivas porque sabe que elas indicam a verdade e o correto.

Arcesilao foi o primeiro acadêmico a criticar tal concepção estoica de representação, dialogando com Zenão de Cítio. Eis a reconstrução do debate por Cícero:

Nenhum dos predecessores de Zenão jamais explicitamente formulou ou mesmo sugeriu o ponto de vista de que uma pessoa poderia não sustentar opiniões - e não somente que poderia fazê-lo, mas que fazê-lo era necessário para o sábio. Arcesilao pensou que esse ponto de vista era tanto verdadeiro quando honrado, bem como correto para o sábio. Então perguntou a Zenão [...] o que aconteceria se o sábio não pudesse apreender nada, já que era uma marca da sabedoria não sustentar opiniões. Zenão respondeu [...] que o sábio não sustentaria qualquer opinião porque haveria algo apreensível. Então, o que seria? Uma representação [visum - a tradução latina de Cícero para o termo grego phantasía], suponho. Bem, que tipo de representação? Zenão a definiu assim: uma representação do que é, estampada, impressa e moldada como o que é. Após isso, Arcesilao prosseguiu perguntando o que aconteceria se uma representação verdadeira fosse como uma representação falsa. Neste momento, Zenão foi esperto o suficiente para ver que nenhuma representação poderia ser apreensível se uma que advém do que é fosse tal que houvesse outra semelhante, advinda do que não é. Arcesilao concordou que essa era uma boa adição à definição, tendo em vista que nem uma representação falsa, nem uma representação verdadeira semelhante a uma falsa era apreensível. Então 
ele lançou-se a trabalhar nesses argumentos para demonstrar que não há representação de algo verdadeiro tal que não haja uma semelhante de algo falso. (Cícero, Academica Posteriora 77$)^{2}$

Talvez retoricamente Arcesilao concede a Zenão que o sábio não assente a opiniões, que é infalível. Mas, no caso de não haver algo sobre o que se possa estar certo, visto que não há representação compreensiva desse algo, somente se pode ser tão infalível quanto o sábio ideal recusando o assentimento, uma vez que não há aí nada que previna contra o erro e o engano. Zenão tem que concordar que o sábio deverá reter o assentimento quando não tiver certeza. Então, a fortiori, o homem ordinário, diante da impossibilidade de conhecer o que é o certo, deve igualmente reter o assentimento. E sua retenção será ainda maior que a do sábio, uma vez que a maioria de suas ações é opinada, mesmo que pragmaticamente corretas.

Assim, segundo Arcesilao, podem ocorrer, tanto para o sábio quanto para o homem comum, situações em que não se pode distinguir entre a verdade e a falsidade das percepções por duas razões:

(1) Porque as coisas que representam são objetivamente indiscerníveis umas das outras:

[...] alguém que olhasse para Publius Servilius Germinus e pensasse que estava olhando para seu gêmeo Quintus teria uma representação não persuasiva (visum quod percipi non posset), porque suas representações verdadeiras e falsas não são distinguíveis por qualquer marca [...] Ainda, se não houver tal similaridade entre os homens, e quanto às estátuas? Está a me dizer que Lisipo não poderia ter feito uma centena de Alexandres, um igual ao outro, se tivesse usado o mesmo bronze, o mesmo processo, a mesma ferramenta, etc.? Diz-me qual marca usarias para distingui-las! E quanto a estampar uma centena de selos do mesmo tipo na cera com seu anel? Serias realmente capaz de encontrar um meio de distingui-los? (Cícero, Academica Posteriora 84-86).

(2) Porque o sujeito que percebe está com sua capacidade de discernimento afetada, como nos recorrentíssimos exemplos das ilusões, da loucura e dos sonhos (Cícero, Academica Posteriora 88-91).

Assim, de acordo com os critérios estoicos, uma representação é compreensiva se e somente se indica com clareza como o objeto é verdadeiramente. A essa

\footnotetext{
${ }^{2}$ Compare com Sexto, Contra os Lógicos, 157: "Se o sábio está entre os que assentem, o sábio está entre os que opinam. Mas o sábio, na verdade, não está entre os que opinam - pois, de acordo com eles [estoicos], a opinião é uma marca da tolice e uma causa de vícios — portanto, o sábio não está entre os que assentem. $\mathrm{E}$, se assim é, ele necessariamente recusará o assentimento sobre tudo. Mas recusar assentir não é nada além de suspender o juízo".
} 
representação se deve assentir. Por outro lado, deve-se suspender o juízo (ou reter o assentimento) diante de representações cujo discernimento não é claro. Portanto, por haver uma zona de penumbra em que a diferença entre uma representação compreensiva e uma não compreensiva não é clara, deve-se, de acordo com o próprio critério estoico, suspender o juízo sobre a possibilidade de distinguir entre as aludidas representações, pelo que se deve prescindir da necessidade da distinção entre as representações como critérios da verdade e da ação correta.

A resposta estoica (de Zenão) vem por três vias:

R1- Asserir que, se as pessoas comuns podem realmente ser confundidas em inúmeras situações, o sábio estoico, por seu turno, é capaz de discernir entre os dois tipos de representação (Cf. Cícero, Academica Posteriora 20, 56-58);

R2- Afirmar que duas coisas não podem ser idênticas (aparallaxía - Cf. Cícero, Academica Posteriora 50, 54-56);

R3- Afirmar que os acadêmicos, ao tentar suspender o juízo sobre a possibilidade de distinção, pretendem suspender o juízo sobre tudo, acabando por verem-se incapazes de agir (apraxía).

Arcesilao contra-argumenta como se segue:

CA 1- Se o sábio estoico é capaz de discernir entre o falso e o verdadeiro, ele mesmo torna-se o derradeiro critério, além dos outros três anteriores. E, se assim é, então o critério de sabedoria do sábio é ele mesmo, o que é uma inaceitável circularidade (Cf. SVF III, 138);

CA 2- Se é necessária uma distinção não evidente, como o homem comum pode saber de sua realidade? Talvez o sábio estoico, por ser sábio, o saiba; mas, uma vez que ele é o critério de sua própria sabedoria, voltamos a CA 1 (e a SVF III, 138 em diante);

Agora, detalhemos o argumento de Arcesilao contra a acusação de apraxía, segundo a qual a suspensão de juízo sobre tudo torna a vida impossível (CA 3). Para os estoicos, os seres humanos se diferenciam dos outros animais porque possuem uma alma racional, pelo que um dos impulsos que temos para a nossa autopreservação (no estado último da humana oikeíosis) é a manutenção da nossa faculdade diretriz (hēgemonikón) que nos torna capazes de assentir (synkatáthesis). Assim, uma vez que as 
representações compreensivas não são coercitivas de sua verdade, devemos assentir a elas, tornando nossas ações louváveis e sábias.

Em contrapartida, se, segundo Arcesilao, devemos prescindir do assentimento, devemos, consoante os estoicos: (1) abrir mão da faculdade comandante que nos define como humanos, prescindindo de nossa própria natureza humana, sendo levados à apraxía e violando o princípio da oikeíōsis; (2) abrir mão da nossa própria felicidade, tendo em vista que ela só é atingível se agirmos de acordo com as representações compreensivas que, para tal, precisam ser distinguidas e conhecidas.

A saída de Arcesilao para os dois aspectos da acusação de apraxía recorre mais uma vez à própria argumentação e aos conceitos da Stoá. Para Arcesilao, teremos uma regra para a ação mesmo se retivermos o assentimento: o eúlogon (o "razoável", no sentido cético do termo), que seria um critério consensual que, mesmo sem compromisso com a verdade, pode suscitar ações convenientes (kathếkonta) ou corretas (katorthốmata), considerando a repetição dos fenômenos e a probabilidade e tornando a felicidade disponível (Cf. Sexto, Contra os Lógicos I, 158).

Então, àqueles que questionam:

[...] como pode alguém que suspende o juízo não correr para uma montanha ao invés de para a banheira, ou levantar-se e caminhar para a porta ao invés de para a parede quando pretende ir ao mercado? (Plutarco, Contra Colotes 1122E; compare com Cícero, Academica Posteriora 37-38) ${ }^{3}$.

Arcesilao responde que:

Para aqueles que estão atentos e escutam, o argumento decorre assim. A alma tem três movimentos: representação, impulso e assentimento. $\mathrm{O}$ movimento da representação não podemos remover, mesmo que quiséssemos; mas, no momento em que encontramos coisas, temos uma representação e somos afetados por esta. O movimento do impulso, quando advindo da representação, ativamente move uma pessoa aos objetos apropriados, tendo em vista que ocorre um tipo de mudança de escala e inclinação [...] Então, aquele que suspende o juízo sobre tudo não remove esse movimento, mas usa o impulso que o leva naturalmente ao que parece apropriado. Qual é, pois, a única coisa que evitam? Somente aquilo no que a falsidade e o engano são engendrados - a opinião e o assentimento precipitados [...] Pois a ação requer duas coisas: uma representação de algo apropriado e o impulso em direção ao objeto apropriado que apareceu. Nenhum desses está em conflito com a suspensão do juízo. (Plutarco, Contra Colotes 1122A-F).

\footnotetext{
${ }^{3}$ Esse argumento ecoa aquele de Aristóteles na Metafisica (1008 b 14-22), sobre o que falaremos à frente.
} 
Carnéades, posteriormente, desenvolve uma concepção cética de representação, sustentando que o que importa nas ações não são as teorias que as fundamentam, mas seu resultado pragmático; e que, para ações corretas, há um critério prático consensual e extraído da vida dos homens comuns: o que é persuasivo ou plausível (pithanós). Carnéades defende essa noção através de um argumento epistemológico:

Seu primeiro argumento [...] é aquele segundo o qual ele fundamenta que nada está qualificado para ser um critério de verdade: nem a razão, nem a percepção sensível, nem as aparências, tampouco qualquer coisa que haja, pois todas elas em conjunto desapontam-nos. (Sexto, Contra os Lógicos I, 159).

Não obstante quais sejam as considerações que se façam sobre um critério, ou qualquer que ele seja (sentidos ou razão, por exemplo), ele deve sempre servir como uma fronteira entre o verdadeiro e o falso, tanto no âmbito epistemológico quanto no ético. Ora, o critério estoico de verdade é a representação compreensiva e, consequentemente, critério também da ação correta no âmbito ético. Assim, seguindo e aprofundando o ataque de Arcesilao, Carnéades distingue, na representação, dois aspectos: sua relação com o objeto que ela representa e sua relação com o sujeito que a percebe. Então se a representação é acuradamente conforme ao objeto, ela é verdadeira; por outro lado, se convence o sujeito de que realmente é verdadeira, levando-o a assentir, é persuasiva (e plausível). Ademais, se uma representação é verdadeira, isso independe do sujeito que percebe, uma vez que sua verdade se dá através de sua conformação com o objeto que a gera; e também, se ela é persuasiva, isso independe do objeto, uma vez que a representação persuade o sujeito, tanto da verdade quanto da falsidade.

Se realmente estivermos, enquanto sujeitos, submetidos exclusivamente ao caráter persuasivo das representações e, além disso, se não tivermos um critério para discernir a verdade, considerando que verdade e falsidade são conhecidas e asseridas a partir da conformidade das representações com os objetos correspondentes - e não segundo qualquer critério subjetivo -, então deveremos prescindir totalmente da categoria "verdade" para pautar nossas ações e nosso conhecimento, pois bastar-nosiam a persuasão e a plausibilidade.

Por outro lado, se os estoicos retrocedem e argumentam que a "verdade" se situa no eixo representação/sujeito, Carnéades está preparado para reutilizar os argumentos já 
empregados por Arcesilao sobre a dubiedade da razão e dos sentidos dos seres humanos contra a solidez monolítica da sabedoria do sábio estoico idealizado ${ }^{4}$.

Diante disso, os estoicos reagem treplicando que a mente deve ser convenientemente treinada através da lógica para eliminar as interferências que possam afetar o discernimento. Uma vez que isso seja feito e os obstáculos para o conhecimento sejam removidos, as representações corretas impelem o assentimento (Sexto, Contra os Lógicos I, 257). Dessa forma, o sábio é capaz de proficientemente discernir as representações compreensivas das outras, utilizando seu treinamento lógico e epistemológico para que a ação nunca seja precipitada e ele nunca seja tentado a concordar com o falso.

Assim, Carnéades, em consonância com Arcesilao, rejeita a concepção estoica de representação compreensiva, persistindo na suficiência do persuasivo como critério pragmático para a ação. Os estoicos, por outro lado, também persistem argumentando que, sem a representação compreensiva, não há critério para a ação correta, tendo em vista que tudo seria incerto (Cícero, Academica Posteriora 32), o que tornaria a vida impossível (Eusébio de Cesareia, Preparação para o Evangelho, 14.7.15.5-6). Ao que Carnéades retorque que há diferença entre algo ser incerto e ser não evidente, e que se, por um lado, tudo é incerto, por outro lado, nem tudo é não evidente. Ou seja, ainda que sejam evidentes, as coisas são incertas, uma vez que podemos ser enganados e mesmo assim assentir erroneamente, pelo que deveríamos suspender o juízo e agir exclusivamente conforme a persuasão causada pelos fenômenos (Eusébio de Cesareia, Preparação para o Evangelho, 14.7.15.5).

Consequentemente, se o persuasivo é suficientemente eficiente no âmbito da ação prática, por outro lado, em epistemologia, representa uma ruptura com a exigência helenística tradicional do critério para o conhecimento e para a verdade. Nesse sentido, podemos entender a posição de Carnéades como um clamor para que os homens abandonem as teorias morais e se atenham à pragmática, na qual as representações persuasivas são um critério que torna a vida possível, não conduzindo à inatividade:

O ponto de vista de [Carnéades] é de que há duas categorias de representações: a primeira, subdividida através do princípio de que algumas são apreensíveis e outras não; a segunda, através do princípio de que algumas são persuasivas e outras não. Ora, os

\footnotetext{
${ }^{4}$ Ver: Cícero, Academica Posteriora 47-49.
} 
argumentos acadêmicos contra os sentidos e contra a perspicuidade referem-se à primeira categoria e não devem ser dirigidos à segunda. Assim, seu ponto de vista, como diz Clitômaco, "é que, enquanto não há representações que se possam apreender, há muitas que se podem aprovar. Seria contrário à natureza se não houvesse representações persuasivas" - e o resultado seria a completa subversão da vida. (Cícero, Academica Posteriora 99).

Como observa Sexto Empírico (Esboços pirrônicos I, 230), Carnéades deliberadamente escolhe aderir a determinadas representações, fazendo-as seu critério para a ação, diferentemente de Arcesilao, que evitava o assentimento e a adesão a um tipo de representação específica em detrimento de outras. Assim, com Carnéades, o ceticismo adota uma postura dogmática quanto à noção de representação.

\section{O posicionamento de Epicteto quanto ao debate cético-estoico em torno do conceito} de representação tal como visto na diatribe 1.5

Vimos acima que os critérios estoicos da verdade e da ação correta são a adesão à representação compreensiva e que há três critérios básicos que indicam quando uma representação é compreensiva, quais sejam: (i) a derivação de um objeto existente; (ii) a representação acurada do tal objeto; (iii) a representação do objeto na mente através dos órgãos sensoriais (DL 7.46). Arcesilao, dialogando com Zenão de Cítio, tenta mostrar que mesmo o sábio deve reter o assentimento em ocasiões nas quais não se pode distinguir entre uma representação verdadeira e uma falsa, pelo que a representação compreensiva não deve ser o critério da ação correta. Os estoicos, por sua vez, respondem que o sábio é sim capaz de efetuar as distinções que os homens comuns não alcançam e que a suspensão de juízo generalizada resulta em apraxía. Os céticos contraargumentam que a afirmação do sábio estoico como capaz de efetuar a distinção o torna o próprio critério, que, por isso, se torna totalmente inacessível ao homem comum e circular. Isso nos leva ao cerne da distinção entre o conceito estoico e acadêmico de representação. Para aqueles, o que distingue o homem dos demais animais é justamente a faculdade diretriz, pela qual se assente ou não às representações, quer dizer, às concepções que temos sobre aquilo que produz uma modificação em nossa alma. Assim, prescindir desse assentimento, como o quer Arcesilao, é fundamentalmente impossível para o ser humano, pois isso significaria ter de abrir mão da própria natureza humana. Arcesilao responde a isso com o critério do razoável (eúlogon), que guiaria a 
ação reta sem compromisso com a verdade. Carnéades introduz, por sua vez, o critério do persuasivo ou plausível, amparando-se no argumento epistemológico da incerteza de todas as coisas, deliberadamente escolhendo aderir a determinadas representações, fazendo-as seu critério para ação prática, diferentemente de Arcesilao, que evitava sistematicamente qualquer assentimento. Carnéades cria, assim, um critério dogmático positivo.

$\mathrm{Na}$ diatribe 1.5, Epicteto insere-se nesse debate, adotando a noção estoica de representação. De fato, em Diatribes I.27 ele nos diz: "De quatro modos as representações nos advém: pois ou é algo e assim se afigura; ou não é algo, nem se afigura como sendo; ou é e não se afigura; ou não é e se afigura <como sendo>" Assim, Epicteto distingue entre quatro tipos de representação, quais sejam: (i) é algo e assim parece; (ii) não é algo e não parece sê-lo; (iii) é algo e não parece sê-lo; (iv) não é algo, mas parece sê-lo. (i) e (ii) seriam representações compreensivas, nas quais temos a percepção de algo e o reconhecimento dela como tal ou não temos a percepção de algo e não a reconhecemos como tal. Mas (iii) e (iv) não seriam representações compreensivas, pois em (iii) e (iv) temos a percepção de algo, mas a reconhecemos como outra coisa: em (iii) não conseguimos reconhecer o que causa a percepção; em (iv), pensamos que o que causa a percepção é coisa diversa do que é. $\mathrm{O}$ assentimento acertado ou errôneo, por sua vez, é àquela parte da representação capaz de ser verdadeira ou falsa, que Epicteto chama de dógma ou hypólepsis. Veja-se, por exemplo, o capítulo 16 do Encheirídion:

Quando vires alguém aflito, chorando pela ausência do filho ou pela perda de suas coisas, toma cuidado para que a representação [phantasía] de que ele esteja envolto em males externos não te arrebate, mas tem prontamente à mão que não é o acontecimento [tó symbebēkós] que o oprime (pois este não oprime outro), mas sim a opinião [dógma] sobre $<$ o acontecimento $>{ }^{6}$

Em Diatribes 1.27.2 e 15, Epicteto menciona conjuntamente acadêmicos e pirrônicos, parecendo não distingui-los. $\operatorname{Dobbin}^{7}$ (2008, p. 99) afirma que o argumento

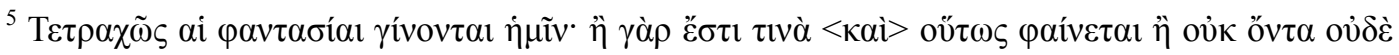

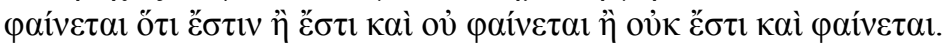

${ }^{6}$ Cf. Diatribes 2.6.21.1; 2.9.14.2; 2.14.22.3; 3.16.9.2; 3.16.11.1; 3.16.13.2; 4.6.14.3; Encheirídion de Epicteto 1.1.2; 20.1.3; 31.1.2.

${ }^{7}$ Dobbin $(2008$, p. 99) especula que o ataque de Epicteto aos Acadêmicos teria provocado a resposta de Favorino em livro hoje perdido que é mencionado por Galeno (Dos meus próprios livros 11), que havia, por sua vez, produzido uma resposta em livro apoiando Epicteto, livro que também não nos chegou. Entretanto, sua asserção carece totalmente de evidências que a apoiem.
} 
nessa diatribe aplica-se igualmente a acadêmicos e pirrônicos. Porém, logo nas primeiras linhas da diatribe, Epicteto dirige-se a quem "põe-se contra coisas excessivamente manifestas". Segundo Sexto Empírico (Esboços pirrônicos I, 1-5), há três tipos de investigadores: os que asserem que descobriram a verdade sobre o tema investigado; os que asserem a inapreensibilidade total da verdade; e os que permanecem investigando. Os primeiros são, para Sexto, os dogmáticos positivos, como Aristóteles, Epicuro e os estoicos; os segundos são os acadêmicos; os terceiros, os pirrônicos. Desse modo, ao referir-se aos que rejeitam o que é manifesto, Epicteto deve ter em mente os que afirmam a inapreensibilidade total, ou seja, os acadêmicos, não os pirrônicos, que, ademais, seguem um procedimento que está de acordo com o que se manifesta (Esboços pirrônicos I, 17) e têm um critério quádruplo para ação baseado nas afecções sensíveis, na coerção da natureza, na observância às leis e costumes e na atividade constante, o que evita a acusação da apraxía (Esboços pirrônicos I, 21-24).

Epicteto também condena os que rejeitam as coisas manifestas por seu estado de petrificação, tanto intelectual quanto do sentido de vergonha, apontando como sintomas desse estado: (1) o não assentimento ao que é visível - demonstrado acima como uma crítica direta aos acadêmicos, e que não vale para os pirrônicos - e (2) a não renúncia a proposições em conflito. Mais uma vez, o sintoma (2) não se remete aos pirrônicos, uma vez que toda a dýnamis de sua conduta depende precisamente da investigação de respostas possíveis para uma questão, da percepção do conflito entre essas respostas e também de sua equipolência e mútua excludência, o que suscita uma aporia que demanda que se suspenda o juízo, evitando a adesão às proposições em conflito, levando à imperturbabilidade.

Somente poder-se-ia deduzir que Epicteto refere-se ao pirronismo tomando-se a passagem "Se alguém estiver de tal modo disposto que não possa nem seguir nem compreender nada, também esse homem pensamos estar em más condições" (1.5.5) como se remetendo à dýnamis pirrônica. Desse modo, caso esteja a dialogar com os pirrônicos, para Epicteto o pirronismo impede o prosseguimento da ação por causar uma aporia e uma akatalepsía generalizada. Mas se é assim e este seja um argumento epicteteano que acusa o pirrônico de apraxía, então Epicteto erra o ponto, uma vez que, como demonstramos mais acima, o pirrônico não incorre em apraxía, pois tem um critério quádruplo para a ação. Entretanto, podemos afirmar que Epicteto não visa aqui 
os pirrônicos. Prova disso é a seguinte passagem da diatribe 1.5:

Muitos de nós tememos a mortificação do corpo e tudo inventaríamos para não cair em tal estado, mas da mortificação da alma descuidamos por completo. (5) E, por Zeus, em relação à própria alma, se alguém estiver de tal modo disposto que não possa nem seguir nem compreender nada, também esse homem pensamos estar em más condições. Mas se o sentido de vergonha e de dignidade de alguém estiver mortificado, chamamos isso ainda de "força"!

Aqui vemos Epicteto traçar uma analogia entre o estado de entrevamento físico, que todos buscam evitar, e o estado mental equivalente, cuja gravidade não é percebida tão facilmente. Neste estado, diz-nos Epicteto, não se consegue compreender nem seguir um argumento. Já a petrificação da faculdade de se envergonhar (aidốs) Epicteto relaciona imediatamente ao ceticismo dogmático, mais particularmente à contradição performática em que recai o cético dogmático negativo diante de uma questão como “Estás acordado?”. Pois, ao responder que é incapaz de saber que está acordado ou não, o cético dogmático negativo supõe o interlocutor real e o estado de vigília, e se contradiz performaticamente. Isto é: quem age de modo semelhante nega-se a assentir ao que é evidente não por não considerá-lo evidente, mas por não aceitar as regras do jogo dialético ${ }^{8}$. Quanto ao que adota a posição deste último, não há argumento que se lhe possa aplicar, visto que ele não participa real e lealmente do jogo dialético, mas apenas finge fazê-lo. Quanto ao intelectualmente petrificado, tampouco cabe um argumento, visto que está em estado no qual é incapaz de compreender um raciocínio.

Em 1.5.6, Epicteto faz referência ao argumento do sonho numa perspectiva dialética, buscando forçar o oponente imaginário ${ }^{9}$ a contradizer-se. Assim, como observamos, ao indagar ao oponente se ele tem ciência de que está acordado, a resposta cética padrão segundo a qual a representação de estar acordado em um sonho em nada se diferencia da representação de estar realmente acordado tem, para Epicteto, como causa a incapacidade de envergonhar-se, pois tal réplica é uma evidente contradição performática. $\mathrm{O}$ argumento de Epicteto, aqui, é semelhante àquele apresentado pelo estagirita na Metafisica: o famoso ad hominem endereçado aos que negam o princípio de não-contradição (Metafísica, 1008 b 2-22). A argumentação ad hominem é um

\footnotetext{
${ }^{8}$ Quais sejam: (i) dois interlocutores podem se contradizer; (ii) um mesmo interlocutor não pode se contradizer. Cf. Wolf, 1996, p. 16.

9 Epicteto usa frequentemente o recurso de criar um oponente imaginário, que é um procedimento característico do estilo diatríbico (Cf. Aune, 2003, p. 128).
} 
procedimento de refutação que consiste em opor o que diz o adversário ao que ele realmente pensa e faz. Na passagem da Metafísica em questão, Aristóteles se indaga se alguém poderia realmente não crer no princípio de não-contradição, o que seria o caso se agisse de modo contraditório. Porém, a mera observação dos atos de seres humanos em plena posse de suas capacidade cognitivas evidencia uma conduta não-contraditória, ficando, desse modo, demonstrado por refutação que um ser humano não pode realmente crer que o princípio de não-contradição seja falso:

Por que, com efeito, caminha para Mégara e não fica parado, quando crê que é preciso caminhar? E por que, ao raiar da aurora, não avança sobre um poço ou um precipício se por acaso os encontra, mas claramente os evita, como quem não crê que cair seja nãobom e bom? É, pois, evidente que considera melhor um e não melhor outro. E, se é assim, também considerará necessariamente que tal coisa é homem e tal outra não é homem, e que isto é doce e aquilo não é doce. Assim, não busca nem julga por igual todas as coisas. (Metafísica, 1008 b 14-22)

\section{Quanto à presente tradução e as Diatribes de Epicteto}

O pensamento de Epicteto chegou-nos através de Lúcio Flávio Arriano, aluno de Epicteto que, entre seus 18 e 19 anos, foi estudar com o mestre em Nicópolis, lá permanecendo entre 105 e 113. Nesta época escreveu as Diatribes de Epicteto $^{10}$. Originalmente havia ao menos oito livros, dos quais nos chegaram apenas quatro, sendo trinta diatribes no primeiro livro, vinte e seis no segundo e no terceiro, e apenas treze no quarto. O nome atual em grego é aquele presente no mais antigo códice de que dispomos (e arquétipo de todos os demais): o Bodleianus Graecorum Miscellaneorum 251 (s), do fim do século XI ou do início do século XII, atualmente conservado na biblioteca Bodleiana, em Oxford. A primeira edição do texto grego é a de Trincavelli, de 1525. Destacam-se a seguir a edição de H. Wolf, de 1560-3, e a edição de Upton, de 1739-41, que serviu de base para o trabalho de Schweighäuser, que estabeleceu o texto pela primeira vez, publicando sua obra entre 1799-1800. O estabelecimento do texto foi novamente corrigido e publicado por Schenkl primeiramente em 1899 e, depois, em edição bastante aperfeiçoada, em 1916. O texto estabelecido por Schenkl serve até nossos dias de base para todas as edições em línguas modernas, e por ele nos guiaremos em nossa tradução.

\footnotetext{
${ }^{10}$ Apesar disso, tanto as Diatribes quando o Encheirídion de Epicteto são considerados, desde a Antiguidade, como obras de Epicteto.
} 
A primeira edição em língua inglesa é a de Elizabeth Carter, de 1758. No século XX disseminaram-se as edições das Diatribes de Epicteto em línguas modernas, sendo as principais, com as quais cotejaremos nossa tradução, as de Oldfather (1925-1928); Souilhé (1948-1965) e Dobbin (1998).

\section{Diatribe 1. 5 - Contra os Acadêmicos ${ }^{11}$}

(1) Se alguém, diz $<$ Epicteto $>$, põe-se contra coisas excessivamente manifestas, não é fácil descobrir um raciocínio ${ }^{12}$ contra ele através do qual poder-se-á dissuadi-lo. (2) Isso não se deve nem à força dele, nem à fraqueza do professor. Mas, quando levado à petrificação ${ }^{13}$, como alguém pode ainda lidar com ele através da razão? (3) Duas são as petrificações: a petrificação intelectual ${ }^{14}$ e a petrificação do sentido de vergonha ${ }^{15}$, quando alguém, adotando postura beligerante ${ }^{16}$, nem assente coisas visíveis, nem

\footnotetext{
${ }^{11}$ O plano geral da diatribe que ora apresentamos é o seguinte:

Parágrafo 1-5: Afirmação da tese: É impossível comunicar-se racionalmente com alguém que desvia sua razão de seu modo natural de operar.

Parágrafo 6-10: Exemplos de insensibilidade oriunda da perda da capacidade de envergonhar-se moralmente (aidốs) e afirmação que tal insensibilidade é pior que erros da razão.

${ }^{12} \mathrm{O}$ manuscrito está danificado entre o parágrafo 1-2. A conjectura estabelecida é a seguinte: $h e u<$ rein lóg $>$ on.

${ }^{13}$ Quanto à ideia de petrificação, cf. Cícero, Ad fam, 9.8.1; Plutarco, Contra Colotes 1122b-c; Diógenes Laércio 7.47.

${ }^{14}$ Noētikós.

${ }^{15}$ Tó entreptikón: aqui como sinônimo de aidốs. Aidếmôn: 'digno', 'decente', 'que tem autorespeito', 'que tem decoro'. Cf. Diatribes $1.25 .4 ; 1.3 .4 ; 1.16 .7 ; 2.1 .11 ; 2.2 .4 ; 2.8 .23 ; 2.10 .15 / 18$; $2.20 .32 ; 2.22 .20 / 30 ; 3.7 .27$; 3.17.5; 3.18.6; 3.22.15; 4.1.106; 4.2.8; 4.3.1-2/7-9; 4.4.6; 4.5.21-2; 4.8.33; 4.9.6/9/11; 4.12.6; 4.13.19-20; Encheirídion 33.15, 40; Fragmento 14. Para aidếmôn em conjunção com pistós, cf. Diatribes $1.4 .18-20 ; 1.25 .4 ; 1.28 .20-1 / 23 ; 2.4 .2 ; 2.8 .23 ; 2.10 .22-$ $3 / 29 ; 2.22 .20 / 30 ; 3.3 .9-10 ; 3.7 .36 ; 3.13 .3 ; 3.14 .13 ; 3.17 .3 ; 3.23 .18 ; 4.1 .161 ; 4.3 .7 ; 4.9 .17$; 4.13.13/15; Encheirídion 24.12; 16; 23; 26; 40.6. A concepção tradicional estoica, segundo nos informa Diógenes Laércio (7.126), caracteriza o virtuoso como andreîos (corajoso, viril), sốphrōn (temperante), phrônimos (prudente) e díkaios (justo). Epicteto se distingue (junto com Marco Aurélio - 2.6; 3.6) por enfatizar outros aspectos da virtude e caracterizar o virtuoso como eleútheros (livre), aidếmōn (digno) e pistós (leal, confiável) e, menos frequentemente, gennaîos (nobre), atárachos (imperturbável), eustathếs (equilibrado) e megalóphrōn (que tem sentimentos elevados, que tem a alma grande). O aidémôn é aquele que tem seu sentimento de vergonha e auto-respeito intacto. Isso, para Epicteto, "é uma capacidade natural e distintamente humana de auto-avaliação, manifesta em atitudes como vergonha e respeito por si mesmo" (Cf. Kamtekar, 1998, p. 136).
} 
renuncia a proposições que estão em conflito ${ }^{17}$.

(4) Muitos de nós tememos a mortificação do corpo, e tudo inventaríamos para não cair em tal estado, mas da mortificação da alma descuidamos por completo. (5) E, por Zeus, em relação à própria alma, se alguém estiver de tal modo disposto que não possa nem seguir nem compreender nada, também esse homem pensamos estar em más condições. Mas se o sentido de vergonha e de dignidade de alguém ${ }^{18}$ estiver mortificado, chamamos isso ainda de "força"! 19

(6) - Apreendes ${ }^{20}$ que estás acordado?

- Não, diz < o mortificado>, pois quando tenho a representação de que estou acordado num sonho, em nada se diferencia esta representação daquela ${ }^{21}$.

(7) Ainda posso com ele dialogar? E que fogo ou ferro devo lhe aplicar para que ele perceba que está mortificado? (8) Ele, percebendo, finge o contrário. É ainda pior que um cadáver ${ }^{22}$. (9) Esse <homem> não é capaz de ver um conflito <entre proposições $>^{23}$ : está em más condições. Aquele, sendo capaz de vê-la, não é movido, nem progride - está numa condição mais lamentável ainda. A dignidade e o sentido da vergonha lhe foram extirpados ${ }^{24}$. (10) A faculdade racional não lhe foi amputada, mas tornou-se embrutecida. Eu chamo isso de força? Absolutamente não! Caso contrário, também $<$ chamaria de força $>$ a $<$ capacidade $>$ dos catamitos $^{25}$ de fazer e falar em

${ }^{16}$ Paratetagménos: particípio de paratássō, que significa na voz ativa literalmente "pôr-se em ordem de batalha" e, nas vozes média e passiva, "preparar-se, recusar obstinadamente". Cf. Marco Aurélio, 8.48; 11.3. Cf. Epicteto, Diatribes 1.27.6; 2.20.1.; 3.3.4; 4.1.136.

${ }^{17}$ Machómena: quando relativo aos axiómata, as proposições da lógica estoica, refere-se a proposições que estão em conflito ou que se contradizem.

${ }^{18}$ Aidếmon.

${ }^{19}$ Dýnamis: provavelmente significando aqui "força moral". Dobbin (2007) traduz por "strength of character"; Souilhé (2002), por "force".

${ }^{20}$ Katalambáneis: presente indicativo segunda do singular de katalambánō: "apreender", forma verbal do katalếpsis (apreensão cognitiva). Quanto à akalēpsía ('incognicibilidade') cética, cf. Cícero, Academica Posteriora 2.47-8; 51-4; 88-90; Sexto, Esboços pirrônicos 1.104, 113, 209.

${ }^{21}$ Quanto à distinção estoica entre sonho e realidade, cf. Diógenes Laércio 7.50. Sobre o ataque epicurista a esta doutrina estoica, cf. Diógenes de Oinoanda, fragmento 9.

${ }^{22}$ Quantos aos parágrafos 7-9: Cf. Diatribes 4.5.21; 2.21.6

${ }^{23}$ Máchē: literalmente "conflito", “combate". Na lógica estoica, são ditas machómena (conflitantes) as proposições contraditórias.

${ }^{24}$ Cf. Epicteto, Diatribes 2.15; Cícero, Acad. Post. 2.9. 
público tudo o que lhes sobrevêm.

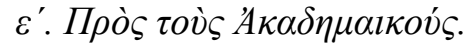

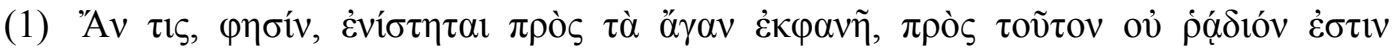

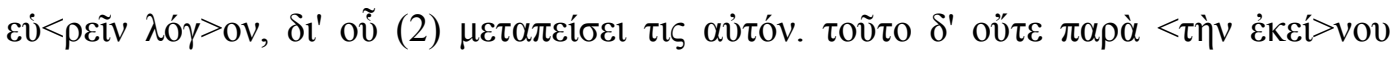

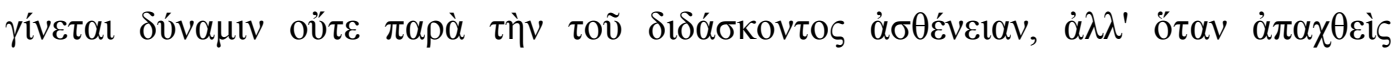

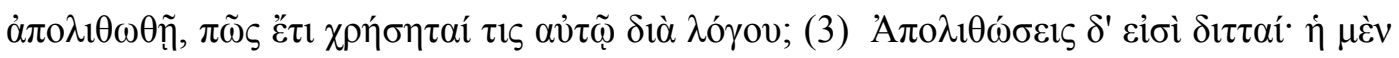

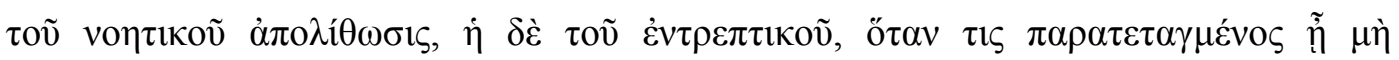

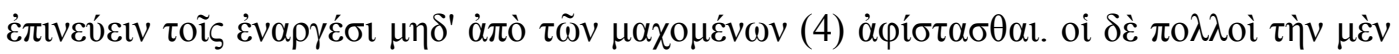

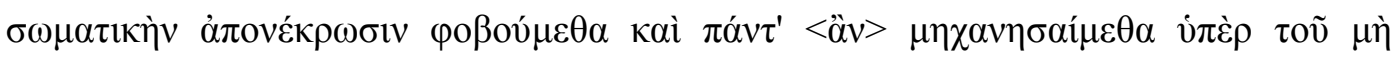

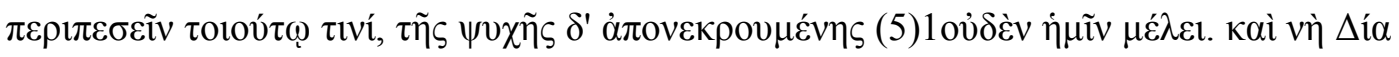

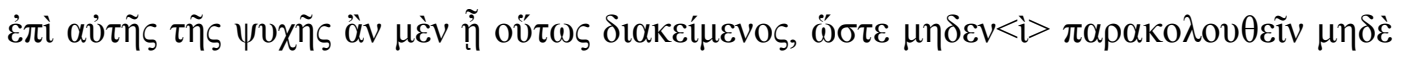

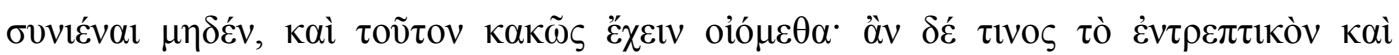

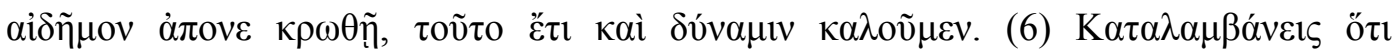

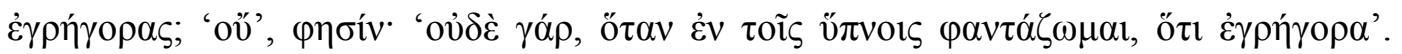

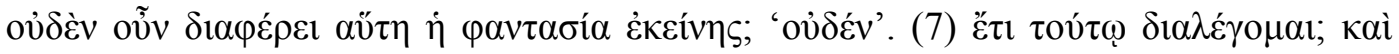

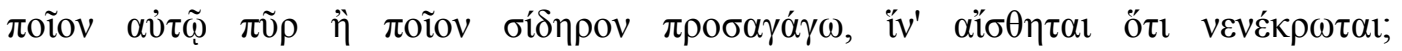

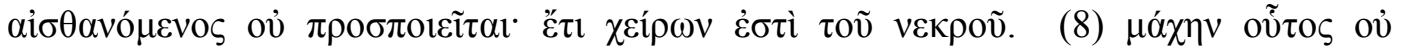

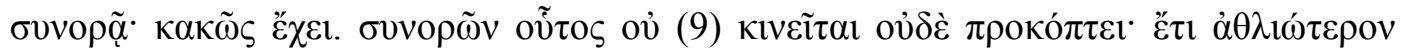

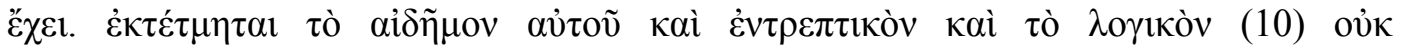

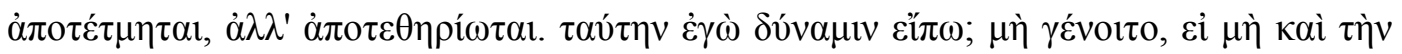

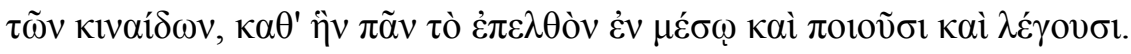

Aldo Dinucci

Rodrigo Pinto de Brito Universidade Federal do Sergipe

\footnotetext{
${ }^{25}$ Kinaidos: catamito, o amante homossexual passivo pré-adolescente ou adolescente em uma relação de pederastia entre dois homens no mundo antigo, sobretudo em Roma. O termo latino catamitus relaciona-se a Ganimedes, o jovem que, segundo a mitologia grega, fora seduzido por Zeus.
} 


\section{Bibliografia}

Aristóteles. Metaphysics. Trad. Tredennick. Londres: Oxford University, 1999.

Aune, D. E. The Westminster Dictionary of New and Early Christian Literature and Rhetoric. Luisville: Westminster, 2003.

Brito, Rodrigo. Da coerência pragmática da dýnamis cética em uma perspectiva dialética. Rio de Janeiro, Puc-Rio, 2013. Disponível em: http://www2.dbd.pucrio.br/pergamum/tesesabertas/1111974_2013 completo.pdf.

Carter, E. All the works of Epictetus, wich are now extant, consisting of his Discourses, preserved by Arrian, in four books, the Enchiridion and Fragments. Londres: 1758.

Cícero. On the nature of gods. Academics. Trad. H. Rackham. Harvard: Loeb, 1933.

Cícero. Letters to Friends, Volume I: Letters 1-113. Trad. B. Shackleton. Harvard: Loeb, 2001.

Dinucci, A. Introdução ao Manual de Epicteto. 3a. Edição. São Cristóvão: EdiUFS, 2012. Disponível em: http://seer.ufs.br/index.php/prometeus/article/view/815/720

Diógenes de Oinoanda. Supplement to Diogenes of Oinoanda: The Epicurean inscription. Trad. Martin Ferguson Smith. Nápoles : Bibliopolis, 2003.

Diógenes Laércio. Lives of Eminent Philosophers, vol. I, II. Trad. R. D. Hicks. Harvard: Loeb Classical Library, 1925.

Epictetus. Entretiens. Livre I. Trad. Joseph Souilhé. Paris: Les Belles Lettres, 2002.

Epictetus. Epictetus Discourses book I. Trad. Dobbin. Oxford: Clarendon, 2008.

Epictetus. $O$ Encheirídion de Epicteto. Trad. Aldo Dinucci; Alfredo Julien. Coimbra: Imprensa da Universidade de Coimbra, 2014. Disponível em: https://bdigital.sib.uc.pt/ jspui/bitstream/ 123456789/171/1/eBook\%20-\%20Epicteto.pdf DOI: 10.14195/978-989-26-0825-9

Epictetus. O Encheirídion de Epicteto. Edição Bilíngue. Trad. Aldo Dinucci; Alfredo Julien. São Cristóvão: EdiUFS, 2012. Disponível em: http://seer.ufs.br/index.php/

prometeus/article/view/816/721

Epictetus. Testemunhos e Fragmentos. Trad. Aldo Dinucci; Alfredo Julien. São Cristóvão: EdiUFS, 2008. Disponível em: http://seer.ufs.br/index.php/prometeus/ article/view/ 802/701

Epictetus. The Discourses of Epictetus as reported by Arrian; Fragments; Encheiridion. Trad. Oldfather. Harvard: Loeb, 2000.

Eusébio de Cesareia. Preparação para o evangelho. IN: HOLMES, M. W. The Apostolic Fathers: Greek texts and English translations. Michigan: Baker Academic, 2007.

Galeno. Exhortation à l'étude de la médecine. Trad. V. Boudon. Paris: Les Belles Lettres, 2002.

Galeno. Medicine, volumes i, ii, iii. Trad. I. Johnston. G. H. R. Horsley. Harvard, Loeb, 2011. 
Kamtekar, R. Aidws in Epictetus. IN: Classical Philology, Vol. 93, No. 2, 1998, p. 136160 .

Marco Aurélio Antonino. Marcus Aurelius. Trad. C. R. Haines. Harvard: Loeb Classical Library, 1916.

Plutarco. Moralia, Volume XIV: That Epicurus Actually Makes a Pleasant Life Impossible. Reply to Colotes in Defence of the Other Philosophers. Is Live Unknown"a Wise Precept? On Music. Trad. Benedict; De Lacy. Harvard, Loeb, 1967.

Schenk1, H. Epicteti Dissertationes ab Arriano Digestae. 2a . Edição. Leipzig: Teubner, 1916.

Schweighäuser, J. Epicteteae Philosophiae Monumenta. 5 volumes. Leipzig: Teubner, 1799-1800.

Sexto Empírico. Against the Logicians. Trad. R. G. Bury. Harvard: Loeb Classical Library, 1935.

Sexto Empírico. Against the Professors. Trad. R. G. Bury. Harvard: Loeb Classical Library, 1949.

Sexto Empírico. Outlines of Pyrrhonism. Trad. R. G. Bury. Harvard: Loeb Classical Library, 1933.

Trincavelli. Arriani Epictetus Graeche. Veneza: 1535.

Upton, J. Epicteti quae supersunt Dissertationes ab Arriano Collectae. 2 volumes. Londres: 1739-41.

Von Arnim, H. Stoicorum Veterum Fragmenta vol. 1: Zeno or Zenonis Discipuli. Berlim: De Gruyter, 2005.

Von Arnim, H. Stoicorum Veterum Fragmenta vol. 2: Chrysippi Fragmenta Logica et Physica. Berlim: De Gruyter, 2005.

Von Arnim, H. Stoicorum Veterum Fragmenta vol. 3: Chrysippi fragmenta moralia. Fragmenta Successorum Chrysippi. Berlim: De Gruyter, 2005.

Wolf, H. Arriani Commentariorum de Epicteti Disputationibus. Basiléia: 1560-3.

Wolff, F. Les Trois Langage-mondes in La Liberté de L'Esprit. Hachete: Paris, 1996. 